\title{
Mosaic 22q I I.2 microdeletion syndrome: diagnosis and clinical manifestations of two cases
}

\author{
Ashutosh Halder*1, Manish Jain ${ }^{1}$, Madhulika Kabra ${ }^{2}$ and Neerja Gupta ${ }^{2}$
}

Address: ${ }^{1}$ Department of Reproductive Biology, All India Institute of Medical Sciences, New Delhi, India and ${ }^{2}$ Department of Pediatrics, Pediatrics Genetics Unit, All India Institute of Medical Sciences, New Delhi, India

Email: Ashutosh Halder* - ashutoshhalder@gmail.com; Manish Jain - om_704@yahoo.co.in; Madhulika Kabra - madhulikakabra@hotmail.com; Neerja Gupta - neerja17@gmail.com

* Corresponding author

Published: 10 August 2008

Molecular Cytogenetics 2008, I:18 doi:10.1186/1755-8166-1-18
Received: 17 June 2008

Accepted: 10 August 2008

This article is available from: http://www.molecularcytogenetics.org/content///I//8

(C) 2008 Halder et al; licensee BioMed Central Ltd.

This is an Open Access article distributed under the terms of the Creative Commons Attribution License (http://creativecommons.org/licenses/by/2.0), which permits unrestricted use, distribution, and reproduction in any medium, provided the original work is properly cited.

\begin{abstract}
Chromosome 22qll.2 microdeletion syndrome is due to microdeletion of $22 \mathrm{ql}$ I.2 region of chromosome 22. It is a common microdeletion syndrome however mosaic cases are very rare and reported only few previous occasions. In this report we describe two unrelated male children with clinical features consistent with 22q I 1.2 microdeletion syndrome characterized by cardiac defect, facial dysmorphism and developmental deficiency. One of the cases also had trigonocephaly. Interphase \& metaphase FISH with 22ql I.2 probe demonstrated mosaicism for hemizygous deletion of $22 \mathrm{q} I \mathrm{I} .2$ region. Mosaicism is also observed in buccal cells as well as urine cells. Parents were without any deletion. These two cases represent rare cases of mosaic $22 q$ I I.2 microdeletion syndrome.
\end{abstract}

\section{Background}

The 22q11.2 microdeletion syndrome is the most common microdeletion syndrome with an estimated incidence of one in 4000 births [1]. It has a wide phenotypic spectrum. Almost all cases result from a common deletion of chromosome 22q11.2 locus. Diagnosis of this microdeletion syndrome is based on prometaphase banding cytogenetics [2], fluorescent in situ hybridization (FISH) [3], array comparative genomic hybridization (aCGH) [4], quantitative fluorescent polymerase chain reaction (QFPCR) [5] with polymorphic micro satellite marker and multiplex ligation dependent probe amplification (MLPA) [6]. Interphase FISH is the prime method for diagnosis of mosaicism. Interphase FISH, being the only way to analyze large number of cells individually \& quickly, has the ability to diagnose mosaicism including low level very easily and reliably. Diagnosis of 22q11.2 microdeletion mosaicism through FISH on amniocytes \& cord blood cells [7], on peripheral blood lymphocytes $[8,9]$ and on cardiac tissue [9] have been reported. In this report we describe two male children with clinical features of 22q11.2 microdeletion syndrome and FISH analysis showed mosaicism for a deletion in the critical region (22q11.2) in peripheral blood nucleated cells (both metaphase \& interphase cells). Furthermore, one of the children had trigonocephaly (premature closure of metopic suture) in addition to features of 22q11.2 microdeletion syndrome despite low level of deleted cells. Trigonocephaly was reported only once in the literature [10]. We here report two rare cases of mosaic 22q11.2 microdeletion syndrome.

\section{Case report \\ Case I}

A two years and ten months male child was referred from Fateyabad, Haryana, India to our hospital for cardiac mal- 
formation (tetralogy of Fallot) and facial dysmorphism. Pediatric geneticist referred the child to us to evaluate for 22q11.2 microdeletion syndrome. The child was born to a 23 year-old mother at 33 weeks 5 days by vaginal delivery in a local private hospital. He was $1400 \mathrm{gm}$ at birth and was in nursery for first 20 days after birth. He was first born child of the couple. His record of length and head circumference was not available. There was no history of antenatal complications. Suckling was defective throughout infancy for which he was spoon fed until one year of age and never breast fed. He had recurrent episodes of upper respiratory infection including fever since infancy for which he was admitted several times in private hospital for the treatment. His milestone was delayed; unable to speak, walk or stand up even at age of 2 years ten months. He has no dyspnoea or cyanosis. There was no similar problem in the family excepting squint in mother and beta thalassaemia major in paternal side.

Physical examination revealed dysmorphic features \& generalized hypotonia. He had short \& broad nose, small mouth, down turn upper lip, hypertelorism, telecanthus and squint (Fig. 1A). Ears were low set, deficient in vertical diameter and dysplastic. Palate was high arched. Hands \& fingers were long and slender. His weight was $9 \mathrm{~kg}$ and height was $75.5 \mathrm{~cm}$ (both below $3^{\text {rd }}$ percentile). Head circumference was $45 \mathrm{~cm}$ (below -2SD/below $2^{\text {nd }}$ percentile), however proportionate to height \& weight. His developmental quotient was between $41-45 \%$ of expected. Ophthalmologic examination was revealed squint. Extensive cardiovascular work up including echocardiography revealed mild pulmonary stenosis, large malaligned ventricular septal defect, dilated aortic root and was suggestive of tetralogy of Fallot. CT scan of head \& brain was normal. There was no hypocalcemia. Conventional cytogenetics from lymphocyte culture was normal.

Since the patient had findings strongly suggestive of 22q11.2 microdeletion syndrome FISH study to detect a possible deletion in the critical 22q11.2 region was done using PAC/BAC clones specific for 22q11.2 locus (RP5882J5 \& CTA-154H4 obtained from Uniba Biologia, Italy, by curtsy of Prof. M Rocchi). Interphase FISH was done using $1 \mathrm{ml}$ of blood obtained from the patient. Blood nucleated cells washed in phosphate buffer saline solution three times before 30 minutes hypotonic treatment (50 mMol KCL) and fixation in methanol:acetic acid solution (3:1 ratio). Cells re-suspended in $100 \mathrm{ul}$ fresh fixative. Approximately $20 \mathrm{ul}$ cell suspension was used to prepare a slide. PAC/BAC clones were grown in LB broth, DNA extracted and about 1 ug DNA was labeled with green flurochrome (FITC) or red flurochrome (Cy3) by nick translation method. About $100 \mathrm{ng}$ labeled probe was used for FISH. FISH analysis was carried out using Olympus

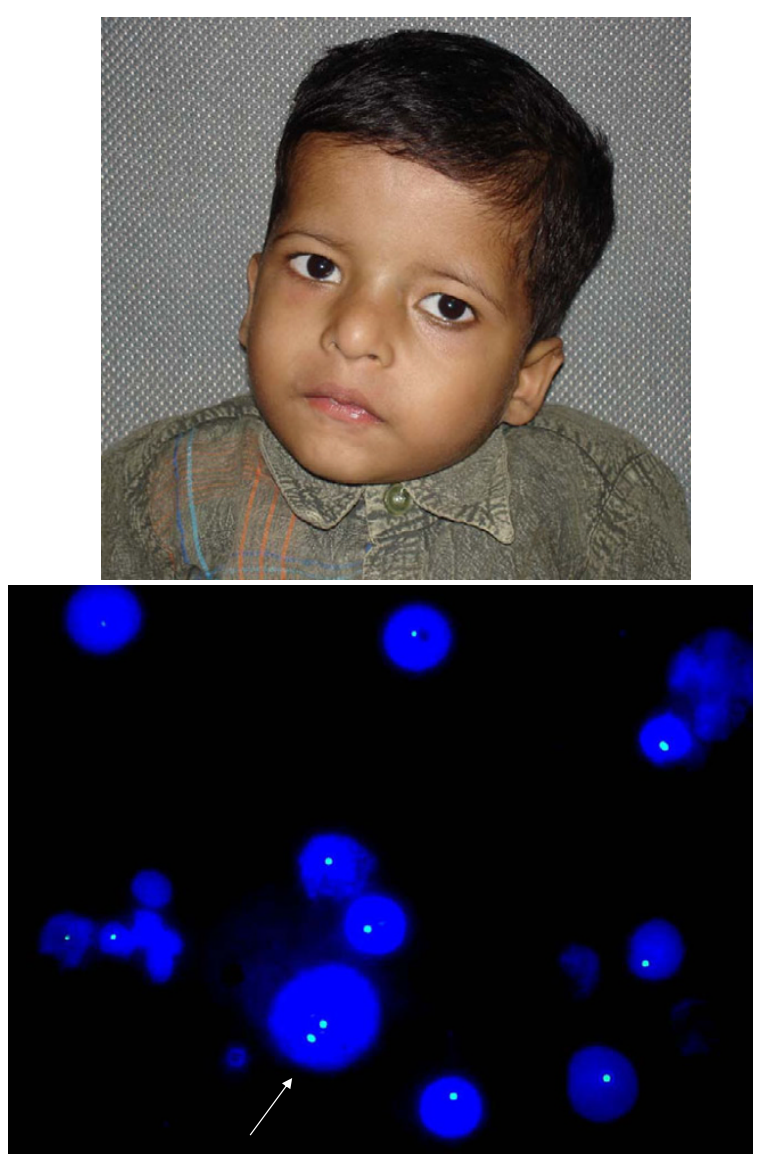

\section{Figure I}

A is showing broad nose, square shaped tip of nose, small philtrum, hypertelorism, telecanthus, squint and low set ears. B is showing 22q I .2 FISH with deletion (most cells) and without deletion (arrow) on interphase cells obtained from peripheral blood.

BX51 microscope with epifluorescence attachment and image was captured through spectral imaging system. A total of 1312 interphase nuclei were scored. Interphase FISH result showed $1100 \quad(83.8 \%)$ nuclei with hemizygous deletion for 22q11.2 locus and 210 (16\%) nuclei with normal diploid state (Fig. 1B). Normal control cases displayed two signals in approximately $98 \%$ nuclei whereas positive controls displayed hemizygous deletion in approximately $98 \%$ nuclei. This finding was conclusive for mosaic 22q11.2 microdeletion with presence of low level of normal cells. FISH on metaphase spread pick up deletion in all excepting one of 25 metaphases studied. Interphase FISH was also carried out on buccal cells and urinary cells as described before [11] to find out whether mosaicism restricted to blood or generalized. Mosaicism was confirmed in all three types of cells (Table 1). Parents were also screened for deletion and results were negative. 
Table I: Details of FISH results of cases and their parents

\begin{tabular}{|c|c|c|c|c|c|}
\hline Parameters & $\begin{array}{l}\text { One Signal } \\
\text { (\%) }\end{array}$ & $\begin{array}{l}\text { Two Signals } \\
\text { (\%) }\end{array}$ & $\begin{array}{l}\text { Other Signals } \\
\text { (\%) }\end{array}$ & $\begin{array}{l}\text { Total } \\
\text { Cells }\end{array}$ & Remarks \\
\hline \multicolumn{6}{|l|}{ Patient I } \\
\hline Blood Interphase & $\begin{array}{l}1100 \\
(83.8)\end{array}$ & $0210(16)$ & $0002(0.2)$ & 1312 & $16 \%$ normal cells \\
\hline Blood Metaphase & 0024 & 0001 & 0000 & 0025 & One normal cell (4\%) \\
\hline Buccal Cells & $\begin{array}{l}0014 \\
(77.8)\end{array}$ & $0004(22.2)$ & 0000 & 0018 & $22.2 \%$ normal cells \\
\hline Urinary Cells & $\begin{array}{l}0008 \\
(88.9)\end{array}$ & $0001(11.1)$ & 0000 & 0009 & II.I\% normal cells \\
\hline Mother's Blood (interphase) & 0000 & 0100 & 0000 & 100 & Normal \\
\hline Father's Blood (interphase) & 0001 & 0081 & 0001 & 0083 & Normal \\
\hline \multicolumn{6}{|l|}{ Patient 2} \\
\hline Blood Interphase & $121(11.6)$ & $925(88.4)$ & 000 & 1046 & $88.4 \%$ normal cells \\
\hline Blood Metaphase & $006(15)$ & $034(85)$ & 000 & 040 & $85 \%$ normal cells \\
\hline Buccal Cells & $008(13.8)$ & $050(86.2)$ & 000 & 058 & $86.2 \%$ normal cells \\
\hline Urinary Cells & $007(14.6)$ & $04 \mid(85.4)$ & 000 & 048 & $85.4 \%$ normal cells \\
\hline Mother's Blood (metaphase) & 000 & 030 & 000 & 030 & Normal \\
\hline Father's Blood (metaphase) & 000 & 020 & 000 & 020 & Normal \\
\hline
\end{tabular}

\section{Case 2}

A one and half year old male child was referred from a village near Sirsa, Haryana, India to our hospital for cardiac malformation and facial dysmorphism. Pediatric geneticist referred the child to us to evaluate for 22q11.2 microdeletion syndrome. The child was born to a 27 year-old mother at term by vaginal delivery at local hospital. He was $1750 \mathrm{gm}$ at birth. He was second born child of the non-consanguineous couple and his elder 3 years old sister was normal. His record of length and head circumference at birth was not available. There was no history of antenatal complications. However, early neonatal period was complicated by unconjugated hyperbillirubinemia that was managed by phototherapy. Suckling was normal however prone to have recurrent episode of vomiting in later part of infancy following intake of foods other than milk. His milestone was grossly delayed. He has significant dyspnoea since last six to seven months. There was no similar problem in the family in either side.

Physical examination revealed dysmorphic features \& generalized hypotonia. Most prominent feature was trigonocephaly with metopic prominence leading to forehead prominence. His head circumference was $45 \mathrm{~cm}$ (below $2 \mathrm{SD} /$ below $2^{\text {nd }}$ percentile). He had short \& broad nose, small mouth, wide philtrum, thin upper lip, hypertelorism, telecanthus and upward slanting almond shaped eyes (Fig. 2A). Ears were low set. Ophthalmologic \& auditory examination revealed no abnormality. He had central cyanosis and significant clubbing of fingers. Extensive cardiovascular work up including echocardiography was suggestive of tetralogy of Fallot with reversal of flow. An X ray skull and CT scan (Fig. 2B) of head \& brain was consistent with craniosynostosis (due to premature metopic suture fusion). There was no hypocalcemia. Conventional cytogenetics from lymphocyte culture was normal.

Since the patient had findings suggestive of $22 \mathrm{q} 11.2$ microdeletion syndrome FISH study was done using PAC/ BAC clones specific for 22q11.2 locus (RP5-882J5 \& CTA154H4, obtained from Uniba Biologia, Italy, by curtsy of Prof. M Rocchi). A total of 1046 interphase nuclei were scored. Interphase FISH result showed 121 (11.6\%) nuclei with hemizygous deletion for 22q11.2 locus and 925 (88.4\%) nuclei with normal diploid state. About 15\% metaphase also showed hemizygous deletion (Fig. 2C). Interphase FISH was also carried out on buccal cells and urinary cells to find out whether mosaicism restricted to blood or generalized. Mosaicism was confirmed in all three types of cells (Table 1). Parents were also screened for deletion and results were negative.

\section{Discussion and conclusion}

In this report we have presented two cases of mosaic 22q11.2 microdeletion syndrome. Both of our cases had tetralogy of Fallot along with facial dysmorphism despite low level of deleted cells ( $15 \%)$ in case 2 . Mosaicism in 22 q11.2 microdeletion syndrome is rare and only a few cases [Table 2] have been described in literature [7-9,12] with variable manifestation viz. early death $[8,9]$ to asymptomatic carrier parents [7,9]. Mosaic full monosomy of chromosome 22 that may present similar to 22q11.2 microdeletion syndrome is also rare [Table 2] and reported few occasions [13-17] with variable manifestation. Similarly, reports of mosaic 22q11.2 deletion with duplication also have been described in the literature on 

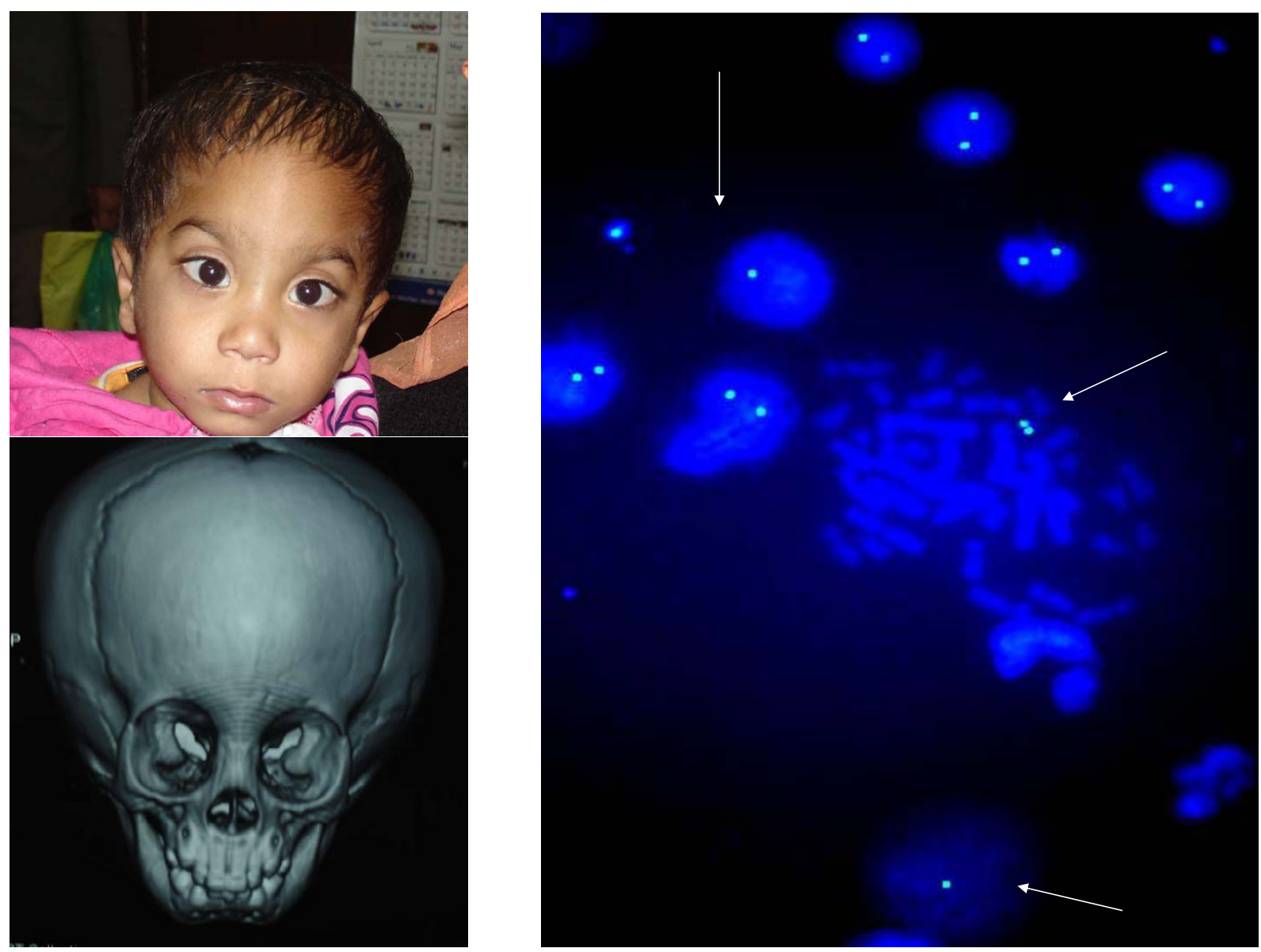

\section{Figure 2}

A is showing broad \& short nose, small moth, wide philtrum, thin upper lip, hypertelorism, telecanthus, upward slanting almond shaped eyes, low set ears and forehead prominence. B is CT scan of skull showing fusion of metopic suture. C is showing 22q I I.2 FISH on lymphocytes (metaphase \& interphase cells) without and with deletions (arrow).

2 occasions [Table 2; [18,19]]. Chen et al. (2004) [7] described a fetus with mosaicism for 22q11.2 hemizygous microdeletion (a ratio of 43 deleted: 57 normal) on amniocytes using FISH technique. The case had cardiac malformation typical of tetralogy of Fallot along with thymic hypoplasia. The father of fetus also had mosaic $22 \mathrm{q} 11.2$ microdeletion (a ratio of 19 deleted: 81 normal) however completely asymptomatic. Patel et al. (2006) [9] reported another case of mosaicism for 22q11.2 microdeletion in fetal cardiac tissue as well in maternal lymphocytes (10\%) by FISH analysis. Similarly, Consevage et al 1996 [8] and Hatchwell et al 1998 [12] reported mosaic 22q11.2 microdeletion in lymphocytes and germ cells, respectively. Dempsey et al (2007) [18] and Blennow et al (2008) [19] reported two more cases of mosaicism. However, patients were mosaic for two abnormal cell lines instead of nor-
mal/abnormal
cell
and
a
deletion
[del(22)(q11.2q11.2)]

lines:

[dup(22)(q11.2q11.2)].

Due to variable manifestation from case to case or familial transmission with this syndrome many authors were looked for mosaicism, including tissue specific. However, outcome were contradictory; some had proven (cardiac tissue) [9] or disproven $[5,20,21]$ while others suspected for gonadal mosaicism [22,23] with different laboratory approaches. Ideal laboratory approach to diagnose mosaicism should be interphase FISH as other method, including QF PCR/MLPA can not detect low level mosaicism due to the presence of a normal cell line, which would mask the appearance of deleted 22q11.2 region. Since interphase FISH analysis can assess large numbers of individ- 
Table 2: Published reports on mosaic 22q I 1.2 microdeletion and mosaic monosomy 22

\begin{tabular}{|c|c|c|c|c|}
\hline SN & References & Case description in brief & Method used & Results \\
\hline & & Mosaic 22qI I.2 deletion & & \\
\hline I & Chen et al 2004 [7] & $\begin{array}{l}\text { Fetus with tetralogy of Fallot \& } \\
\text { thymic hypoplasia } \\
\text { Father asymptomatic }\end{array}$ & $\begin{array}{l}\text { Interphase FISH on amniocytes } \\
\text { Interphase cells from cord blood } \\
\text { Interphase FISH on lymphocytes }\end{array}$ & $\begin{array}{l}61 \% \text { deleted interphase cells } \\
43 \% \text { deleted interphase cells } \\
19 \% \text { deleted interphase cells }\end{array}$ \\
\hline 2 & Consevage et al $1996[8]$ & $\begin{array}{l}\text { Female newborn with facial } \\
\text { dysmorphism, hypoplastic left } \\
\text { heart syndrome \& growth } \\
\text { retardation }\end{array}$ & Metaphase FISH in lymphocytes & $16 \%$ metaphases with deletion \\
\hline 3 & Patel et al 2006 [9] & $\begin{array}{l}\text { Missed abortion at } 16 \text { weeks } \\
\text { gestation } \\
\text { Asymptomatic carrier mother }\end{array}$ & $\begin{array}{l}\text { Interphase FISH on heart tissue } \\
\text { Lymphocytes }\end{array}$ & $\begin{array}{l}\text { Cells with } \& \text { without deletions } \\
10 \% \text { deleted cells }\end{array}$ \\
\hline \multirow[t]{2}{*}{4} & Hatchwell et al 1998 [12] & $\begin{array}{l}\text { Mother with } 2 \text { affected \& one } \\
\text { unaffected child }\end{array}$ & FISH \& haplotype analysis & Germ line mosai-cism in mother \\
\hline & & Mosaic monosomy 22 & & \\
\hline 5 & Pinto-Escalante et al I998 [13] & $\begin{array}{l}\text { Dysmorphism, joint contracture, } \\
\text { scleroderma, hypertrichosis, } \\
\text { hypertonicity, etc }\end{array}$ & $\begin{array}{l}\text { Karyotype from lymphocyte } \\
\text { culture }\end{array}$ & $15 \%$ monosomic cells \\
\hline 6 & Verloes A et al $1987[14]$ & $\begin{array}{l}\text { A child with mild facial } \\
\text { dysmorphism and mentally } \\
\text { deficiency }\end{array}$ & $\begin{array}{l}\text { Karyotype on lymphocytes \& } \\
\text { fibroblast cells }\end{array}$ & $\begin{array}{l}10.5 \% \& 8.3 \% \text { monosomic cells, } \\
\text { respectively }\end{array}$ \\
\hline 7 & Sabui and Chakrobarty 1997 [15] & $\begin{array}{l}\text { Female child with facial } \\
\text { dysmorphism \& failure to thrive } \\
\text { including developmental delay }\end{array}$ & Karyotype on lymphocytes & $70 \%$ monosomic cells \\
\hline 8 & Lewinsky et al 1990 [16] & $\begin{array}{l}\text { Fetal gastroschisis with absent } \\
\text { cerebral diastolic flow }\end{array}$ & Karyotype & Mosaic monosomy 22 \\
\hline \multirow[t]{2}{*}{9} & Moghe et al I98I [17] & $\begin{array}{l}\text { Male child with facial dysmor- } \\
\text { phism, psychomotor retardation, } \\
\text { hypotonia \& syndactyly }\end{array}$ & Karyotype on lymphocytes & $25 \%$ monosomic cells \\
\hline & & $\begin{array}{l}\text { Mosaic } 22 q 1 \text { l.2 deletion \& } \\
\text { duplication }\end{array}$ & & \\
\hline 10 & Dempsey et al 2007 [18] & $\begin{array}{l}\text { Twin newborn, one normal \& } \\
\text { other with cardiac malformation } \\
\text { as well as hypocalcemia, later } \\
\text { delayed development and } \\
\text { recurrent infections }\end{array}$ & $\begin{array}{l}\text { FISH on metaphase of } \\
\text { lymphocytes } \\
\text { FISH on metaphase of skin } \\
\text { fibroblasts } \\
\text { FISH on interphase skin fibroblast } \\
\text { cells }\end{array}$ & $\begin{array}{l}\text { Deletion in } 55 \% \text { cells; duplication } \\
\text { in } 45 \% \text { cells } \\
\text { Deletion in } 86 \% \text { cells; duplication } \\
\text { in } 14 \% \text { cells } \\
80 \% \text { deleted cells }\end{array}$ \\
\hline II & Blennow et al. 2008 [19] & $\begin{array}{l}\text { Girl with dysmorphism but no } \\
\text { cardiac malformation }\end{array}$ & Lymphocytes & $\begin{array}{l}\text { Deletion in } 70 \% \text { cells; duplication } \\
\text { in } 100 \% \text { cells }\end{array}$ \\
\hline
\end{tabular}

ual cells very quickly this technique can pick up even low level of mosaicism. Our second case emphasizes the importance of interphase FISH in the diagnosis of low level of mosaicism despite strong clinical manifestations. To establish a mosaicism, as we followed \& confirmed (on metaphase as well as with another probe), a repeat blood sample should always be analyzed along with other tissues viz. buccal cells (ectodermal origin) \&/or urine cells (endodermal origin). However, one should take precaution before diagnosing a mosaicism that hemizygous signal drop is frequent with interphase FISH (also influenced by type of tissue and probes) [24,25]. In our hand 22q11.2 locus specific probe (RP5-882J5 \& CTA-154H4) provides hemizygous results in $1.76 \%$ interphase lymphocyte nuclei of normal individuals and we had taken care before diagnosing low level mosaicism (i.e., also confirmed by metaphase FISH \& second adjacent probe at 22q11.21 locus i.e., CTA-154H4 BAC clone; metaphase
FISH does not give rise to hemizygous deletion in normal controls).

We also report on the association of trigonocephaly, one type of craniosynostosis, in one child with the mosaic 22q11.2 microdeletion. Yamamoto et al. (2006) [10] reported first time one patient with 22q11.2 microdeletion and craniosynostosis of the metopic suture leading to trigonocephaly. They suggested craniosynostosis of the metopic suture might be a minor complication, although coincidental occurrence cannot be ruled out. Here, we have encountered with another patient of 22q11.2 microdeletion (mosaic) with trigonocephaly derived from craniosynostosis of the metopic suture. This is the second report of a relationship between microdeletion 22q11.2 and trigonocephaly. Although trigonocephaly is rare with 22q11.2 microdeletion, it is commonly seen with monosomy $9 p$ [26]. However, other form of craniosynostosis 
with 22q11.2 microdeletion syndrome is not so rare and reported in some previous occasions [27-31]. Ryan et al. (1997) [31] described five patients of microdeletion 22q11.2 syndrome with craniosynostosis without description of its type. McDonald-McGinn et al. (2005) [30] reported on the presence of craniosynostosis in another four patients with the 22q11.2 microdeletion syndrome. Similarly, De Silva et al. (1995), Karteszi et al. (2005), Dean et al. (1998), etc [27-29] reported some more cases of craniosynostosis in patient with microdeletion 22q11. In light of previous repeated reports of the association, we assume that craniosynostosis including trigonocephaly may be a rare manifestation of the 22q11.2 microdeletion syndrome. However, it seems that $12-15 \%$ mosaicism for $22 q 11.2$ microdeletion may not solely account for the condition and the possibility of another undetected condition can not be ruled out. Craniosynostosis is also commonly seen with other chromosome deletions viz., with chromosome $15 \mathrm{q}$ (del(15)(q15q22.1) [32]; with chromosome 7p- [33-36] and $2 \mathrm{q}-[37]$. Familial transmission of a $22 \mathrm{q} 11.2$ microdeletion accounts for 8 to $25 \%$ of the cases [38,39] and parents with deletions may be asymptomatic or mildly affected. However, none of the parents in our cases were carrier for the microdeletions.

We conclude that mosaic 22q11.2 microdeletion is not very rare if investigated with interphase FISH, can present as severe phenotype even in the presence of low level of deleted cells and trigonocephaly/craniosynostosis may be a rare manifestation.

\section{Competing interests}

The authors declare that they have no competing interests.

\section{Authors' contributions}

AH formulated activity plan, checked results \& interpretated results. He also had reviewed clinical findings, prepared manuscript and responded to the quarries of reviewers. He will be the guarantor of the manuscript. MJ carried out all FISH related activity under guidance of $\mathrm{AH}$. MK and NG were involved in clinical suspicion of the disease and management of the cases. All authors read and approved final manuscript.

\section{Consent}

Written informed consent was obtained from the parent of patients for publication with any accompanying images. A copy of the written consent is available for review by the Editor-in-Chief of this journal [vide additional files 1-2]

\section{Additional material}

\author{
Additional File 1 \\ Consent form 1. \\ Click here for file \\ [http://www.biomedcentral.com/content/supplementary/1755- \\ 8166-1-18-S1.jpeg]

\section{Additional File 2} \\ Consent form 2. \\ Click here for file \\ [http://www.biomedcentral.com/content/supplementary/1755- \\ 8166-1-18-S2.jpeg]
}

\section{Acknowledgements}

We thank Professor Mariano Rocchi (University of Bari, Italy) for resources on molecular cytogenetics (PAC/BAC clones for 22ql I.2 locus). We also thank Indian Council of Medical Research, New Delhi for funding. We are thankful to the families of patients for their cooperation during this study.

\section{References}

I. Oskarsdottir S, Vujic M, Fasth A: Incidence and prevalence of the 22q I I deletion syndrome: a population-based study in Western Sweden. Arch Dis Child 2004, 89: I48-I5I.

2. Franke UC, Scambler PJ, Loffler C, Lons P, Hanefeld F, Zoll B, Hansmann I: Interstitial deletion of $22 \mathrm{qI} I$ in DiGeorge syndrome detected by high resolution and molecular analysis. Clin Genet 1994, 46:187-192.

3. Park IS, Ko JK, Kim YH, Yoo HW, Seo EJ, Choi JY, Gil HY, Kim SJ: Cardiovascular anomalies in patients with chromosome 22qI I.2 deletion: a Korean multicenter study. Int J Cardiol 2007, I I 4:230-235.

4. Mantripragada KK, Tapia-Paez I, Blennow E, Nilsson P, Wedell A, Dumanski JP: DNA copy-number analysis of the 22q I deletion-syndrome region using array-CGH with genomic and PCR-based targets. Int J Mol Med 2004, I 3:273-279.

5. Jianrong L, Yinglong L, Xiaodong L, Cuntao Y, Bin C, Bo W: 22qI I.2 deletion mosaicism in patients with conotruncal heart defects. Birth Defects Res A Clin Mol Teratol 2006, 76:262-265.

6. Jalali GR, Vorstman JA, Errami A, Vijzelaar R, Biegel J, Shaikh T, Emanuel BS: Detailed analysis of 22qII.2 with a high density MLPA probe set. Hum Mutat 2008, 29:433-440.

7. Chen CP, Chern SR, Lee CC, Lin SP, Chang TY, Wang W: Prenatal diagnosis of mosaic 22q I I.2 microdeletion. Prenat Diagn 2004, 24:660-662.

8. Consevage MW, Seip JR, Belchis DA, Davis AT, Baylen BG, Rogan PK: Association of a mosaic chromosomal 22q I I deletion with hypoplastic left heart syndrome. Am J Cardiol 1996, 77:1023-1025.

9. Patel ZM, Gawde HM, Khatkhatay MI: 22q I I microdeletion studies in the heart tissue of an abortus involving a familial form of congenital heart disease. / Clin Lab Anal 2006, 20:160-163.

10. Yamamoto T, Sameshima K, Sekido K, Aida N, Matsumoto N, Naritomi K, Kurosawa K: Trigonocephaly in a boy with paternally inherited deletion 22qII.2 syndrome. Am J Med Genet A 2006, 140: 1302-1304.

II. Halder A, Fauzdar A: Potential use of blood, buccal and urine cells for rapid noninvasive diagnosis of suspected aneuploidy using FISH. J Clin \& Diagn Res 2007, I:32-38.

12. Hatchwell E, Long F, Wilde J, Crolla J, Temple K: Molecular confirmation of germ line mosaicism for a submicroscopic deletion of chromosome 22qI I. Am J Med Genet 1998, 78:103-106.

13. Pinto-Escalante D, Ceballos-Quintal JM, Castillo-Zapata I, Canto-Herrera J: Full mosaic monosomy 22 in a child with DiGeorge syndrome facial appearance. Am J Med Genet 1998, 76:150-153. 
14. Verloes A, Herens C, Lambotte C, Frederic J: Chromosome 22 mosaic monosomy $(46, X Y / 45, X Y,-22)$. Ann Genet 1987, 30:178-179.

15. Sabui TK, Chakraborty AK: Monosomy 22 Mosaicism. Indian Pediatrics 1997, 34:348-352.

16. Lewinsky RM, Johnson JM, Lao TT, Winsor EJ, Cohen H: Fetal Gastroschisis associated with monosomy 22 mosaicism and absent cerebral diastolic flow. Prenatal Diagnosis 1990, 10:605-608.

17. Moghe MS, Patel ZM, Peter JJ, Ambani LM: Monosomy 22 with mosaicism. J Med Genet 198I, 18:7I-73.

18. Dempsey MA, Schwartz S, Waggoner DJ: Mosaicism $\operatorname{del}(22)(q|I .2 q| I .2) / \operatorname{dup}(22)(q|I .2 q| I .2)$ in a patient with features of 22qI I.2 deletion syndrome. Am J Med Genet A 2007, | 43A( ( 0): 1082-1086.

19. Blennow E, Lagerstedt K, Malmgren H, Sahlén S, Schoumans J, Anderlid $B$ : Concurrent microdeletion and duplication of $22 q$ I I.2. Clin Genet 2008, 74:6I-67.

20. Rauch A, Hofbeck M, Cesnjevar R, Koch A, Rauch R, Buheitel G, Singer $H$, Weyand $M$ : Search for somatic 22q I I.2 deletions in patients with conotruncal heart defects. Am J Med Genet A 2004, 124:165-169.

21. Vincent MC, Heitz F, Tricoire J, Bourrouillou G, Kuhlein E, Rolland M, Calvas P: 22qII deletion in DGS/VCFS monozygotic twins with discordant phenotypes. Genet Couns 1999, 10:43-44.

22. Kasprzak L, Der Kaloustian VM, Elliott AM, Shevell M, Lejtenyi C, Eydoux P: Deletion of $22 \mathrm{qII}$ in two brothers with different phenotype. Am J Med Genet 1998, 75:288-29I.

23. Sandrin-Garcia P, Macedo C, Martelli LR, Ramos ES, Guion-Almeida ML, Richieri-Costa A, Passos GA: Recurrent 22q I I.2 deletion in a sib ship suggestive of parental germ line mosaicism in velocardiofacial syndrome. Clin Genet 2002, 61:380-383.

24. lourov IY, Vorsanova SG, Yurov YB: Intercellular Genomic (Chromosomal) Variations Resulting in Somatic Mosaicism: Mechanisms and Consequences. Current Genomics 2006, 7:435-446.

25. lourov IY, Vorsanova SG, Yurov YB: Chromosomal variation in mammalian neuronal cells: known facts and attractive hypotheses. Int Rev Cytol 2006, 249:143-191.

26. Azimi C, Kennedy SJ, Chitayat D, Chakraborty P, Clarke JT, Forrest C, Teebi AS: Clinical and genetic aspects of trigonocephaly: A study of 25 cases. Am J Med Genet Part A 2003, I I A A: I27-I35.

27. De Silva D, Duffty P, Booth P, Auchterlonie I, Morrison N, Dean JC: Family studies in chromosome 22q I deletion: further demonstration of phenotypic heterogeneity. Clin Dysmorphol 1995, 4:294-303.

28. Dean JC, De Silva DC, Reardon W: Craniosynostosis and chromosome 22q I I deletion. I Med Genet 1998, 35:346-347.

29. Karteszi J, Kress W, Szasz M, Czako M, Melegh B, Kosztolanyi GY, Morava E: Partial craniosynostosis in a patient with deletion 22q I I. Genet Couns 2004, I 5:48I-483.

30. McDonald-McGinn DM, Gripp KW, Kirschner RE, Maisenbacher MK, Hustead V, Schauer GM, Keppler-Noreuil KM, Ciprero KL, Pasquariello PJr, LaRossa D: Bartlett S.P., Whitaker L.A., Zackai E.H., Craniosynostosis: another feature of the 22qI I.2 deletion syndrome. Am J Med Genet A 2005, I36A(4):358-362.

3I. Ryan AK, Goodship JA, Wilson DI, Philip N, Levy A, Seidel H, Schuffenhauer S, Oechsler H, Belohradsky B, Prieur M, Aurias A, Raymond FL, Clayton-Smith J, Hatchwell E, McKeown C, Beemer FA, Dallapiccola B, Novelli G, Hurst JA, Ignatius J, Green AJ, Winter RM, Brueton L, Brondum-Nielsen K, Stewart F, Van Essen T, Patton M, Paterson J, Scambler PJ: Spectrum of clinical features associated with interstitial chromosome 22q I I deletions: A European collaborative study. J Med Genet 1997, 34:798-804.

32. Fukushima $Y$, Wakui $K$, Nishida T, Nishimoto H: Craniosynostosis in an infant with an interstitial deletion of 15q [46,XY,del(I5)(q15q22. I)]. Am J Med Genet 1990, 36:209-2 I3.

33. Aughton DJ, Cassidy SB, Whiteman DA, Delach JA, Guttmacher AE: Chromosome 7p-syndrome: craniosynostosis with preservation of region 7p2. Am J Med Genet 1991, 40:440-443.

34. Gong BT, Norwood TH, Hoehn H, McPherson E, Hall JG, Hickman R: Chromosome 7 short arm deletion and craniosynostosis. A 7p-syndrome. Hum Genet 1976, 35: I 17-I 23.

35. Motegi T, Ohuchi M, Ohtaki C, Fujiwara K, Enomoto S, Hasegawa T, Kishi $\mathrm{K}$, Hayakawa $\mathrm{H}$ : A craniosynostosis in a boy with a $\operatorname{del}(7)(\mathrm{p} \mid 5.3 \mathrm{p} 2 \mathrm{I.3})$ : assignment by deletion mapping of the critical segment for craniosynostosis to the mid-portion of 7p21. Hum Genet 1985, 71:160-162.

36. Shetty S, Boycott KM, Gillan TL, Bowser K, Parboosingh JS, Mclnnes $\mathrm{B}$, Chernos JE, Bernier FP: Cytogenetic and molecular characterization of a de-novo cryptic deletion of $7 \mathrm{p} 21$ associated with an apparently balanced translocation and complex craniosynostosis. Clin Dysmorphol 2007, 16:253-256.

37. Nixon J, Oldridge M, Wilkie AO, Smith K: Interstitial deletion of 2q associated with craniosynostosis, ocular coloboma, and limb abnormalities: cytogenetic and molecular investigation. Am J Med Genet 1997, 70:324-327.

38. Digilio MC, Angioni A, De Santis M, Lombardo A, Giannotti A, Dallapiccola B, Marino B: Spectrum of clinical variability in familial deletion 22q I I.2: from full manifestation to extremely mild clinical anomalies. Clin Genet 2003, 63:308-3I3.

39. Driscoll DA, Salvin J, Sellinger B: Prevalence of 22q I I microdeletions in DiGeorge and velo-cardio-facial syndromes: implications for genetic counseling and prenatal diagnosis. J Med Genet 1993, 30:813-817.
Publish with Bio Med Central and every scientist can read your work free of charge

"BioMed Central will be the most significant development for disseminating the results of biomedical research in our lifetime. "

Sir Paul Nurse, Cancer Research UK

Your research papers will be:

- available free of charge to the entire biomedical community

- peer reviewed and published immediately upon acceptance

- cited in PubMed and archived on PubMed Central

- yours - you keep the copyright

Submit your manuscript here:

http://www.biomedcentral.com/info/publishing_adv.asp
BioMedcentral 